\title{
The Model of Customer Experience and Purchase Intention in Online Environment
}

\author{
Muhammad Zahid Maitlo $^{1 *}$, Neelam Jugwani ${ }^{2}$, Rehman Gul Gilal ${ }^{1}$
}

\begin{abstract}
The online purchase intention is very critical and fascinating in today's eenvironment. It has direct involvement in customer decision making in terms of purchase. Thus, corporations use various marketing tools to seize customer attention for product purchase decision. This study provides the model of customer experience and purchase intention in e-environment. A total of 326 internet users were requested to provide the data through distributed questionnaire using non-probability econvenience sampling technique. Further, Analysis of Moment Structure was employed and Structural Equation Model was used to measure the model of customer experience and online purchase intention with customer experience sub-dimension i.e. online hedonic elements, online aesthetics and online functional elements. The result of the study clearly indicates that customer with tremendous experience tends to purchase frequently in an online environment. In other words, customer online experience is directly proportional to purchase intention. Hence, increase in online customer experience will increase purchase intention.
\end{abstract}

Keywords: Customer Experience, Purchase Intention, Structural Equation Model.

\section{Background}

In this globalized era, corporations are seeking modern and advanced tools of how to appeal, attract and capture customer attention as long as possible. Most importantly, to find what makes the customer more happy and comfortable in selecting a particular brand as well as converting them from customers to good stakeholders. Indeed, they are signifying various methods to answer this question in customer behavioral context. In this case, experience has been considered as one of the most powerful and imperative areas of modern marketing in customer psychological perspective. Hence, customer experience has achieved greatest interest of marketers as sources of strategic competitive advantage in today's environment. Strategically, customer experience is a facet to create brand offerings as well as channel trustworthiness for firms and is difficult to imitate by competitors as it has sturdily highest potentiality, consistency, promise fulfillment and brand communication in the experiential economy (Berry, https://doi.org/10.30537/sijmb.v4i1.101

${ }^{1}$ Department of Business Administration, Shah Abdul Latif University, Khairpur Mir's

* Corresponding Author: zahidmaitlo2011@gmail.com

${ }^{2}$ Department of Business Administration, Dadabhoy Institute of Higher Education, Karachi

SIJMB | E-ISSN: 2410-1885; P-ISSN: 2313-1217 @ 2017 Sukkur IBA University - All Rights Reserved 
Carbone, and Haeckel (2002); Kim (2002)). Although marketing activities persuade potential customers in terms of their interaction and interest level, still customer experience has a unique proposition that depends on and varies as per time, place and given environment. Similarly, online environment has its own composition and involvement in terms of customer experience. For example, prior research has given insights of customer experience in regards to online shopping preference on the basis of experience gained by online visitors (Gentile, Spiller, \& Noci, 2007). Garg, Rahman, and Qureshi (2014), found that customers prefer only that website for shopping which provides them better experiences. Shaw and Ivens (2002), found that old customers are more profitable as compared to new ones and have a high tendency of purchasing products if they have good online experience. Therefore, customer experience and customer purchase intention are crucial to investigate in e-environment. Hypothetically, this research empirically explores customer online purchase intentions on the basis of functional, aesthetic and hedonic elements to generate customer experience.

\subsection{Research Momentum}

For the last years, customer experience has become critical and important for almost all business and non-business organizations around the globe. This has caused greatest interest of scholars and researchers to explore and investigate the dimensions of customer experience in various demo-geographical areas of business in numerous industries. Although Customer behavior is dynamic according to their psychological traits as well as situational or environmental influences and physical interactions (Schiffman \& Kanuk, 2000). Similarly, customer interaction in online environment lacks physical elements i.e. product and human tangible presence as compared to other places where there is high involvement of these interactions. It indicates that customer experience with physical (i.e. product and human) interaction and online interaction is different. Thus, the researcher has proposed the model of customer experience and purchase intention in an online environment. In this model, customer experience is divided into three sub-dimensions i.e. online hedonic elements, online aesthetic and online functional elements to measure how these dimensions create customer purchase intention in such e-environment.

\section{Literature review}

\subsection{Customer Experience}

Sundbo and Hagedorn-Rasmussen (2008), define customer experience as "a psychological journey that leaves the customer in reminiscences by executing one thing extraordinary, somewhat erudite, and something incredible or having pleasurable is customer experience". In addition, it is also personal and internal rejoinder for a customer that needs a straight or roundabout interaction with the organization (Meyer $\&$ Schwager, 2007). Customer behavior has building block which is an experience that concerns by means of fantasies, exceptional customer observation and sentiments

Sukkur IBA Journal of Management and Business | Volume 4 No. 1 January - June 2017 @ Sukkur IBA University 
(Holbrook \& Hirschman, 1982). By other means, the experience is par excellent or an event happens and it leaves a thought in the minds of others.

In addition, customers are ever changing their preferences themselves towards marketer's activeness tactics that possess strong customer attention appeals (Yoon, 2013). In a prior era of marketing journalism, organization's main focus was on fast moving consumer goods in terms of providing best products with different attributes (Klaus, Gorgoglione, Buonamassa, Panniello, \& Nguyen, 2013) but this focus has less significance as compared to customer experience in recent times (Maklan \& Klaus, 2011). Additionally, the center of attention in customer perspective is the experience that they acquire when they utilize products and services (Biswas, 2009). Similarly, in terms of maximizing profitability and brand awareness among customers to enhance loyalty among customers, organizations have to pass the hurdle by providing magnificent experience to customers (Garg, Rahman, Qureshi, \& Kumar, 2012; Ismail, 2011). According to a survey by Gurley (2000), it was predicted that customers are filling their online purchasing form but without any purchasing activity, they quit the sequence.

\subsection{Online Functional Elements (OFE)}

It can be defined as the core function of website i.e. usability and interconnectivity elements that are highly related to customer experience in an online environment (Constantinides, 2004; Mathwick \& Rigdon, 2004; Sheu, Su, \& Chu, 2009; Takatalo, Nyman, \& Laaksonen, 2008). In other words, it is important to keep preferred material so that customer can easily complete their task on the web in shorter time frame. Similarly, interconnectivity can highly enrich customer experience in terms of providing customized benefits and supporting online roamers for sharing experiences and information as required and necessary for creating impact (Constantinides, 2004). In other means, better usability and interconnectivity of website can provide better customer experience in e-environment. Further, these elements are important in building good unique customer experience towards behavioral intentions (Constantinides, 2004).

\subsection{Online Aesthetics (OA)}

Systematically, the basic endeavor of internet site of aesthetic characteristics of a firm is to leave a positive consciousness in minds of ultimate clients and motivating them towards offers who are surfing websites in limited time duration (Constantinides, 2004; Constantinides, Lorenzo-Romero, \& Gómez, 2010; Sheu et al., 2009; Sun, 2002). Further, Web users can be attracted by visual display graphics used on websites i.e. font styles, its size and shapes, color combination manuscript clearness, audios (Madu \& Madu, 2002). In a prior study of Mathwick, Malhotra, and Rigdon (2001), the aesthetic web characteristics found significantly related to web users in deciding behavioral intentions (Fogg et al., 2002) these characteristics also work like

Sukkur IBA Journal of Management and Business | Volume 4 No. 1 January - June 2017 @ Sukkur IBA University 
conversationalists or communicators for attracting online consumers in optimistic intentions intended to encourage interaction by means of web services.

\subsection{Online Hedonic Elements (OHE)}

These are the certain customer characteristics that can immerse in online surroundings and get away from their reality, wherever they experience an enchanted environment in contrast with real life environment (Mathwick \& Rigdon, 2004; Sheu et al., 2009; Takatalo et al., 2008). In terms of hedonic significance under discussion, the large extent of investigation has been carried out (Babin \& Attaway, 2000; Darden \& Reynolds, 1971) also has commenced designating as the essential constituent of online purchasing (Burke, 1999; Hoffman \& Novak, 1996). In addition, Consumer does not shop for just to achieving the mission, but they rapidly do shopping for collecting admiration on the experience they have collected (Babin, Darden, \& Griffin, 1994). Similar to real life purchasing, customer preferred online purchasing for the purpose of amusement and what to do something really different that is why they look forward to structured experiences which soak up customers (Kim, 2002; Mathwick et al., 2001).

\subsection{Online Purchase Intention (OPI)}

Shao et al., (2004), define purchase intention as a behavioral aspect of consumer towards utilizing the company services is known as consumer purchase intention. In prior research, it can be planned behavior of the consumer to buy products and services (Dodds, Monroe, \& Grewal, 1991). Customer purchasing behavior is predicted by purchase intention which is a crucial component and enriched in terms of customer context (Fishbein \& Ajzen, 1977). Psychological conditions of decision making are known as customer purchase intentions and rely upon experience that happens in their earlier period with perceived surveillance. Similarly, purchase intentions of customers are their actions which considerably contribute within behavior creation with the help thoughts, certainly, evaluation for external environmental etc. to build customers trail expertise for purchase decision (Dodds et al., 1991; Schiffman \& Kanuk, 2000; Yang \& He, 2011; Zeithaml, 1988).

\subsection{Prior studies on Customer Experience References Key points}

Bilgihan (2016)

Online marketing is expected to be different as they process website information five times faster than older generations and are the most emotional and least loyal customers as compared to all other generations in providing customer experiences

Sukkur IBA Journal of Management and Business | Volume 4 No. 1 January - June 2017 @ Sukkur IBA University 
Bilgihan,

Kandampully, and

Zhang (2016)

Stein and Ramaseshan

(2016)

Amoah et al. (2016)

\section{Rukhsana Gul Gilal (2016)}

Sun (2002)

Hao Suan Samuel, Balaji, and Kok Wei (2015)

Martin, Mortimer, and Andrews (2015)

Homburg, Jozić, and Kuehnl (2015)

Harwood and Garry (2015)
Online shopping environment is dynamic because consumers connections with e-vendors, researchers and professionals that are important for understanding and that create a compelling online user experience

Customer experience elements like touch points, which include; atmospheric, technological, communicative, process, employee-customer interaction, customercustomer interaction and product interaction elements are most important

Customer experience strategy that can enhance customer satisfaction, positive behavioral intentions, growth, and sustainability

The self-concept emerged as a stronger driver for brand experience and consumer brand relationship, then for brand preference and customer satisfaction

Customer experience helps marketers in establishing powerful Brand awareness, brand association, perceived quality, and brand Loyalty

Customer experience is based on a tangible and sensorial experience, staff aspect, aesthetic perception, and location

Antecedents for cognitive and affective experiential states and their influence on outcomes such as online shopping perceived risk, trust satisfaction, and repurchase intentions

Online retailers can focus on cognitive aspects (e.g., website Navigation, functionality, and connectedness) and affective aspects (e.g., website aesthetics, 3-D product presentation, and customization) of the online shopping website in providing holistic online experiences

Customer experience management as one of the most promising marketing approaches in consumer industries

Sukkur IBA Journal of Management and Business | Volume 4 No. 1 January - June 2017 @ Sukkur IBA University 


$\begin{array}{ll}\text { Sekaran and Bougie } & \begin{array}{l}\text { Higher levels of customer role readiness, } \\ \text { technologization, and connectivity positively affect } \\ \text { (2016) }\end{array} \\ \text { different co-creation experience dimensions }\end{array}$

Chen and Lin (2015)

Cho (2015)
Customer experience and perceived value on continuance intention are both respectively significant in marketing approach

The interactive effects of a website experience and order fulfilment are significant. In the interactive mechanism, order fulfilment experience is proven to serve as proximal cause of repurchase intention

\subsection{Conceptual Framework}

\subsubsection{Customer Experience and Online Purchase Intention (CE $\rightarrow$ OPI)}

In today's competitive environment, where survival in the international marketplace is complicated for international or national firms because there are a lot of identical products as well as services available with minimum differences. Beneath such kind of circumstances, customers are experiencing a perfect purchasing during their shopping tour and also fulfill with effective product offerings. Customer experience theory was thoroughly visualized in the mid-80s in the area of consumer behavior (Holbrook \& Hirschman, 1982). This theory of customer experiences seems to actualize a universal understanding among professionals, service scientists and experts in discussion the affairs of customer experiences. Although, in these beginning studies where the most important stream of investigation in the nineties (Pine \& Gilmore, 1999) book on the Experience Economy and in the experiential book of Marketing by Schmitt, another customer experience's concept was revealed. Additionally increased better customer experiences will generate customers purchase intentions (Bellman, Lohse, \& Johnson, 1999). A customer experience is a new but powerful weapon as it strengthens customer purchase intention (Igbaria, Guimaraes, \& Davis, 1995). Cowles, Kiecker, and Little (2002), concludes that the prime focus of web owners should be upon consumer desire values to inspire them beyond their means. Thus, they should be engaged in offering to give greater services as well as values for good experiences (Woodruff, 1997). Similarly, prior scholars and researchers have investigated the effective aspects i.e. hedonic features that can motivate a customer towards purchasing (Arnold \& Reynolds, 2003; Babin et al., 1994; Kim, 2002; Zhou, Dai, \& Zhang, 2007). In addition, the role of hedonic features has been also found significant to propose customer purchase intentions in e-environment (Mare Hassenzahl, Platz, Burmester, \& Lehner, 2000). Further, customer experience may require more aesthetics to enhance purchase intentions and it is the experiences in which they are involved with enjoyment (O'Brien \& Toms, 2010). Online roamers can be engaged by aesthetic appealing visual display graphics that lead to staying web users on websites and lead to construct

Sukkur IBA Journal of Management and Business | Volume 4 No. 1 January - June 2017 @ Sukkur IBA University 
purchase intentions (Madu \& Madu, 2002). Aesthetic features of website pose a strong perception customer minds that stimulate intention towards the purchase (Constantinides, 2004; Constantinides et al., 2010; Sheu et al., 2009). Yang and $\mathrm{He}$ (2011), concludes that customers purchase intentions are highly influenced by their past experiences and what they see at purchase moment. This moment of decision can be enhanced with the help of aesthetic, hedonic elements that will help customers to feel relaxed with joyful interaction (Marc Hassenzahl \& Tractinsky, 2006). Moreover, functional features of the website are also important in building good customer experience towards behavioral intentions (Constantinides, 2004). The functional elements drive comfort-ability of user interface on the website that leads to staying or switches to other websites due to being less user-friendly (Sheu et al., 2009; Takatalo et al., 2008). Hence, the customer would prefer those sites that are well functional in the user interface and interconnectivity (Constantinides, 2004; Mathwick \& Rigdon, 2004; Sheu et al., 2009; Takatalo et al., 2008). Thus, the research hypotheses in light of literature review areas:

$\mathrm{H} 1$ : there is significant influence of customer experience on online purchase intention $\mathrm{H} 2$ : online hedonic elements have significant influence on online purchase intention H3: online aesthetic elements have significant influence on online purchase intention $\mathrm{H} 4$ : online functional elements have significant influence on online purchase intention

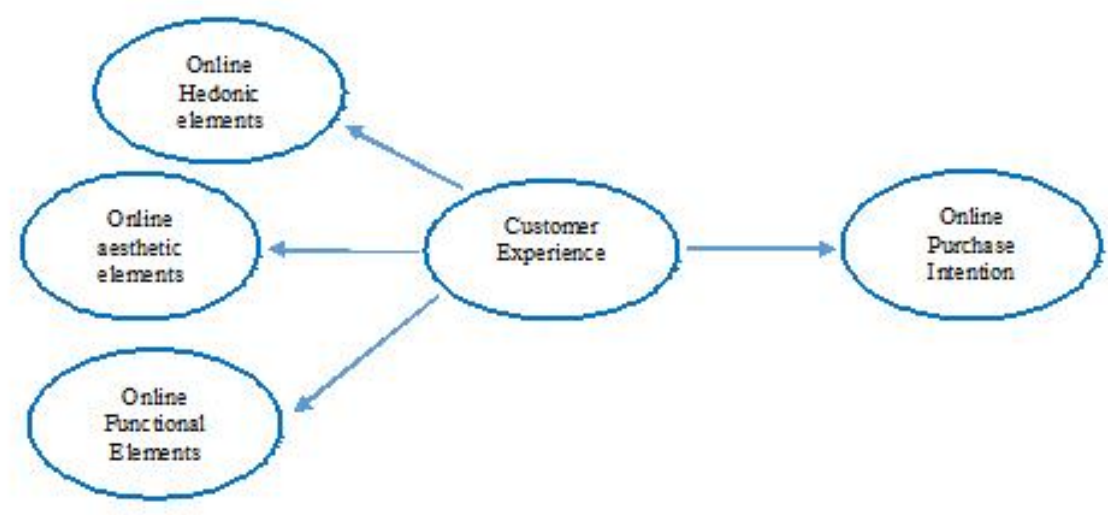

Figure 1: Conceptual Model

\section{Research Methodology}

\subsection{Sample size and data collection}

In this paper, the researcher is predicting online purchase intention by predictor customer experience. Hence, internet users of minimum 18 years were respondents for conducting this study. However, a researcher could not select direct sample size from

Sukkur IBA Journal of Management and Business | Volume 4 No. 1 January - June 2017 @ Sukkur IBA University 
the population due to the list of internet users is not available. Consequently, the researcher has used Non-Probability e-convenience sampling technique. Moreover, a total of 351 internet users contributed to this research by completing research survey. Systematically, the minimum threshold for sample size should be as big as it reduces the chances of error (Babin \& Zikmund, 2015; Sekaran \& Bougie, 2016) and proved to be best in an exploratory study.

Moreover, an online questionnaire was sent to respondents for collecting data, using 'Google Forms' questionnaire tool (www.google.com/forms) by using a Likert scale from 1 for strongly disagree to 5 for strongly agree adopted from (Fang et al., 2014) to measure online hedonic elements, online aesthetics, and online functional elements. Similarly, online purchase intention was measured by using a Likert scale from 1 for strongly disagree to 5 for strongly agree adopted from (Yoo \& Donthu, 2001). The prime focus of researcher was on online internet users and therefore individual who did not have intent access were not important to address. Further, questionnaire link was sent to students, professionals, and academicians using email, Facebook, and LinkedIn along with necessary information about research purpose so that respondents can understand about what they are being asked to record their responses and provide authentic information. Respondents were requested to fill survey questionnaire electronically that was in the English language. A total of 351 respondents participated in this survey. The responses were preceded further in data refining and cleaning phase i.e. missing value elimination (Hair, Black, Babin, \& Anderson, 2010). The data refining and cleaning were performed by using SPSS v-18. In conclusion, a sufficient 326 responses were considered valid for further analysis.

\section{Analysis and Results 4.1. Respondent Profile}

In term of the respondent profile, questionnaire form was composed of demographic details of respondents i.e. gender, age, education, ethnicity, marital status, average monthly income, shopping experience, online shopping frequency. It can be concluded that $66.5 \%$ male customers and $33.4 \%$ female customers were found engaged in the online shopping environment. However, it has been also revealed that $48.4 \%$ young customers with age bracket have a major contribution in this study. Further, respondents in the majority were matric and intermediate qualified customers with $26.6 \%$ followed by $46.0 \%$ of total $100 \%$. Similarly, customers with Sindhi Ethnicity covered a large portion of the sample with $34.6 \%$ and least by Baloch customers with 4.2\%. Moreover, $66.5 \%$ single respondents followed by $36.1 \%$ customers with average monthly income of 21,001-28,000 completed questionnaire. The results of demographic analysis also suggest that majority of $30 \%$ customer were experienced in online shopping with $28.5 \%$ products online purchase frequency per year as shown in table 1 .

Sukkur IBA Journal of Management and Business | Volume 4 No. 1 January - June 2017 @ Sukkur IBA University 
M. Zahid Maitlo et. al. / The Model of Customer Experience and Purchase Intention in Online Environment (pp. 1-17)

\begin{tabular}{|c|c|c|c|}
\hline \multicolumn{4}{|c|}{ Table 1: Respondent Profile } \\
\hline Factors & Profile & Total Number & $(\%)$ \\
\hline \multirow[t]{3}{*}{ Gender } & Male & 217 & 66.5 \\
\hline & Female & 109 & 33.4 \\
\hline & $18-22$ & 158 & 48.4 \\
\hline \multirow[t]{3}{*}{ Age } & $23-26$ & 111 & 34.0 \\
\hline & $27-30$ & 33 & 10.1 \\
\hline & $31+$ & 24 & 7.3 \\
\hline \multirow[t]{7}{*}{ Education } & No Education & 63 & 19.3 \\
\hline & Matriculate & 87 & 26.6 \\
\hline & Intermediate & 85 & 26.0 \\
\hline & Graduate & 58 & 17.7 \\
\hline & Post-Graduate & 33 & 10.1 \\
\hline & Sindhi & 113 & 34.6 \\
\hline & Punjabi & 88 & 26.9 \\
\hline \multirow[t]{3}{*}{ Ethnicity } & Pakhtoon & 47 & 14.4 \\
\hline & Baloch & 14 & 4.2 \\
\hline & Other & 64 & 19.6 \\
\hline \multirow[t]{3}{*}{ Marital Status } & Married & 109 & 33.4 \\
\hline & Single & 217 & 66.5 \\
\hline & No Income & 26 & 7.9 \\
\hline Average Monthly & $7,000-14,000$ & 35 & 10.7 \\
\hline \multirow[t]{4}{*}{ Income (PKR) } & $14,001-21,000$ & 62 & 19.0 \\
\hline & $21,001-28,000$ & 118 & 36.1 \\
\hline & $28,001+$ & 85 & 26.0 \\
\hline & $1-3$ & 71 & 21.7 \\
\hline Online Shopping & $4-6$ & 48 & 14.7 \\
\hline \multirow[t]{3}{*}{ Frequency (Per Year) } & $7-9$ & 93 & 28.5 \\
\hline & $10+$ & 87 & 26.6 \\
\hline & $1-3$ & 77 & 23.6 \\
\hline Online Shopping & $4-6$ & 98 & 30.0 \\
\hline \multirow[t]{2}{*}{ Experience (in Years) } & $7-9$ & 57 & 17.4 \\
\hline & $10+$ & 61 & 18.7 \\
\hline
\end{tabular}

\subsection{Validity Analysis}

The researcher has used Composite Reliability, Cronbach Alpha and Average variance Extracted to measure the internal consistency of scale. These techniques were employed to measure the consistency among variable items used in this study. (Nunnally and Bernstein (1994)), suggested that all items for a latent variable are only effective when their minimum threshold should be 0.70 . Further, all values of constructs are given in table 2 has qualified the minimum standards of tested dimensions on the basis of $\alpha, \mathrm{CR}, \mathrm{AVE}$.

Sukkur IBA Journal of Management and Business | Volume 4 No. 1 January - June 2017 @ Sukkur IBA University 
M. Zahid Maitlo et. al. / The Model of Customer Experience and Purchase Intention in Online Environment (pp. 1-17)

Table 2: Composite Reliability, Cronbach Alpha, Average Variance Extracted

\begin{tabular}{llll}
\hline Constructs & $(\alpha)$ & $(\mathrm{CR})$ & $(\mathrm{AVE})$ \\
\hline Minimum Threshold & $\geq 0.7$ & $\geq 0.7$ & $\geq 0.5$ \\
Online Hedonic Elements & 0.94 & 0.88 & 0.78 \\
Online Aesthetics & 0.88 & 0.91 & 0.81 \\
Online Functional Elements & 0.84 & 0.87 & 0.79 \\
Online Purchase Intention & 0.93 & 0.91 & 0.82 \\
\hline
\end{tabular}

Further, the descriptive statistics is given in the table. It shows mean and standard deviation with minimum and maximum values of total frequency. However, the online functional elements have highest mean value and standard deviation at 0.9. Accordingly, all latent variables were measured with total variable error term variance. Hence, the descriptive analysis indicates adequacy of latent variables as shown in table 3.

Table 3: Descriptive Analysis

\begin{tabular}{llllll}
\hline Constructs & Frequency & Min & Max & Mean & $\begin{array}{l}\text { Standard } \\
\text { Deviation }\end{array}$ \\
\hline Online Hedonic Elements & 326 & 1.23 & 6.00 & 4.7 & 0.7 \\
Online Aesthetics & 326 & 1.89 & 6.00 & 5.1 & 0.9 \\
Online Functional Elements & 326 & 1.57 & 6.00 & 5.7 & 0.9 \\
Online Purchase Intentions & 326 & 1.81 & 6.00 & 5.4 & 1.5 \\
\hline
\end{tabular}

In addition, Pearson correlation was also measured to identify the relationship between all variable used in this model. The result of correlation analysis indicates correlation among used variable in this study is significant at $\mathrm{p} \leq 0.05$.

Table 4: Pearson Correlation Analysis

\begin{tabular}{llll}
\hline Constructs & Frequency & $\begin{array}{l}\text { Correlation } \\
\text { Coefficient (r) }\end{array}$ & Sig Level \\
\hline CE and OPI & 326 & 0.814 & 0.001 \\
OHE and OPI & 326 & 0.725 & 0.001 \\
OAE and OPI & 326 & 0.842 & 0.002 \\
OFE and OPI & 326 & 0.814 & 0.001 \\
\hline
\end{tabular}

\subsection{The Structural Equation Model (SEM)}

The Structural Equation Model analysis was performed by using an advanced version of IBM-SPSS v-18. Analysis of Moment Structure that is widely known as AMOS has some of the key specialties that help p researchers of the world to employ it. For example, it represents the relationship of hypothesized models in non-graphical and graphical paths used in particular research and also generates cross-sectional and linear analysis to produce the model fit index. Hence, this research comprises regression and path analysis. Statically, results of the study indicate that influence of customer experience on online purchase intention is significant at p-value $<0.05$ while the Chi-

Sukkur IBA Journal of Management and Business | Volume 4 No. 1 January - June 2017 @ Sukkur IBA University 
square $(\chi 2)$ value indicates a good fit. Thus, H1 there is significant influence of customer experience on online purchase intention i.e. OPI $\leftarrow$ CE: $\gamma=0.81, t=4.41$, p-value $=0.01$

Table 5: Hypothesis Testing

\begin{tabular}{llllll}
\hline \multirow{2}{*}{ Hypothesis } & Path & $* \gamma$ & $\begin{array}{l}* * \mathrm{t}- \\
\text { value }\end{array}$ & $\begin{array}{l}* * * \mathrm{p}- \\
\text { value }\end{array}$ & Results \\
\hline $\mathrm{H} 1$ & OPI $\leftarrow$ CE & 0.81 & 4.41 & 0.01 & \\
$\mathrm{H} 2$ & OPI & 0.82 & 9.377 & 0.02 & \\
$\mathrm{H} 3$ & OHE & & & & $\begin{array}{l}\text { Strongly } \\
\text { OPI }\end{array}$ \\
H4 & OAE & 0.78 & 9.778 & 0.01 & Supported \\
\hline OPI & OFE & 0.81 & 9.836 & 0.03 & \\
\hline
\end{tabular}

* Gamma $(\gamma), * t \geq 1.96, * * * p \leq 0.05$

\subsection{Measurement of Model}

In addition, the researcher has tested model fitness through various indexes as shown in table 5. Similarly, Incremental fit index, Tucker-Lewis index, Comparative fit index, Chi-square and Root Mean Square error of approximation has been generated to test the model goodness. The overall result in table 5 indicates that model is a good fit at $\chi^{2}=1.75$.

Table 6: Model Fit Index

\begin{tabular}{llcccccc}
\hline Model & Description & $(\chi 2)$ & TLI & CFI & IFI & NFI & RMSEA \\
\hline & Full & & & & & & \\
& $\begin{array}{l}\text { Conceptual } \\
\text { Model }\end{array}$ & 1.75 & 0.97 & 0.98 & 0.96 & 0.95 & 0.62 \\
\hline
\end{tabular}

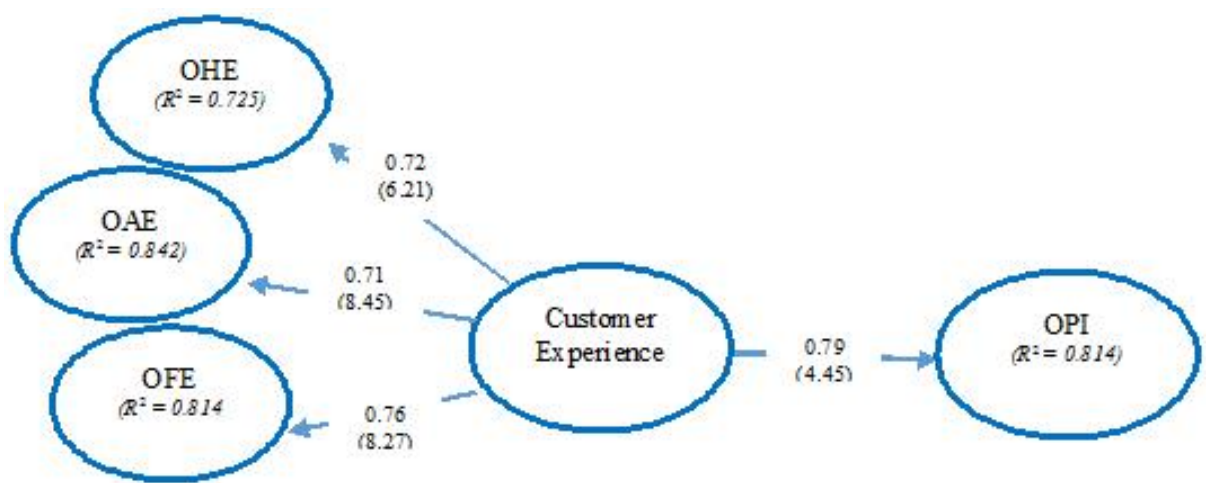

Figure 2: Measurement Model Results based on Main Hypothesis H1

Thresholds: $\chi 2 / d f=2 \leq 1, I F I \geq 0.90, R M S E A \leq 0.08, N F I \geq 0.90$, and $C F I \geq 0.904 .5$ 


\subsection{Hypothesis Testing}

In order to test hypothesized model, Path Analysis and Multivariate analysis were employed. The results of the study indicate and confirm that there is a significant relationship between customer experience and customer online purchase intentions at p-value $<0.05$. It indicates that relationship between customer experience and online purchase intention is significant at $\mathrm{p}$-value $<0.05$ which means null hypothesis. There is no significant relationship between customer experience and online purchase intention is rejected. In addition, other three hypotheses the influence of three customer experience dimensions i.e. OFE, OA, and OHE found significant at OPI $\leftarrow$ OHE: $\gamma=$ $0.82, \mathrm{t}=9.377, \mathrm{p}$-value $=0.02 ;$ OPI $\leftarrow$ OA: $\gamma=0.78, \mathrm{t}=9.778, \mathrm{p}$-value $=0.01 ;$ OPI $\leftarrow$ OFE: $\gamma=0.81, \mathrm{t}=9.836$, $\mathrm{p}$-value $=0.03$. Hence, the overall results of the study indicate that customer experience and its dimensions namely online hedonic elements, online Aesthetics and online Functional elements have a positive significant impact on online purchase intentions.

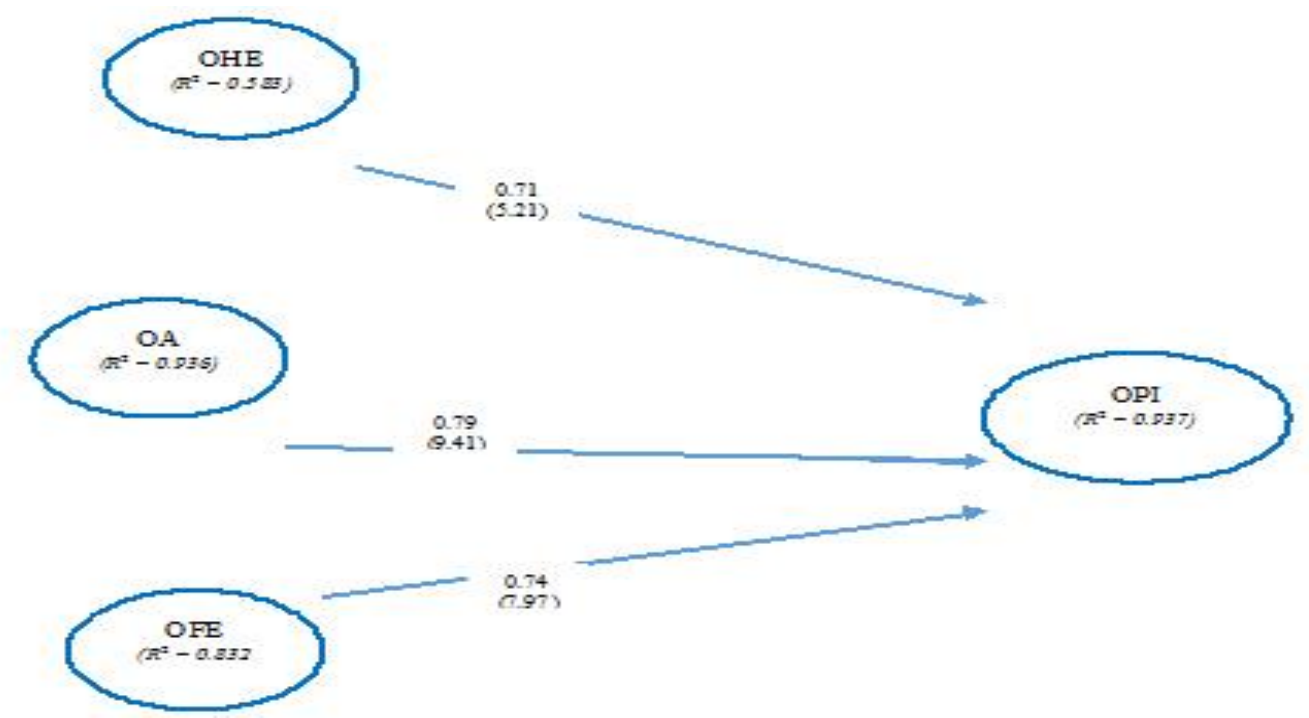

Figure 3: Measurement Model Results based on Hypothesis H2, H3, and H4

Fit Indices Result: $\chi^{2}=447, d f=216, \chi 2 / d f=1.75, C F I=0.98, T L I=0.97, I F I=0.96, N F I=0.95$, RMSEA $=0.062$

\section{Discussion and Implications}

This research aims to explore the influence of customer experience on online purchase intentions in online shopping industry. The results of this study have revealed that there is a significant positive relationship between customer experience and purchase intentions. Although, H1, H2, H3, H4 are accepted (Significance level i.e. $\leq .000$ ) after employing Structural Equation Model. All hypotheses are accepted on the confidence level of $95 \%$. Since it can be concluded that good customer experience generates

Sukkur IBA Journal of Management and Business | Volume 4 No. 1 January - June 2017 @ Sukkur IBA University 
chances of customer purchase intentions of that particular company's product whose website is under customer's experience. Further, it has been proved that there is a significant influence of customer experience on online purchase intentions. In addition, results of this study significantly indicate the influence of customer experience on purchase intentions in an online environment. More specifically, denoting results of all sub-dimensions of customer experience (i.e. Online Hedonic elements, Online Aesthetics, Online functional Elements) also found significant on purchase intention in this study.

In conclusion, it can be said that customer experience causes and is directly linked with purchase intentions in an online environment. In other words, it can be summarized that online shopping website should pay their maximum attention to creating good customer experience by enhancing and improving customer experience stimulators (i.e. Online Hedonic elements, Online Aesthetics, Online Functional elements) that have been proposed and found significant in this study. Similarly, customers tend to purchase more frequent products whenever they find online shopping websites aesthetic, easy user interfaces in functional elements and possess hedonic elements in the online environment. This study entails that customer experience is one of the powerful and strong stimulators that shape customer purchase intentions in the online shopping environment. On other, it can be proposed that customers with strong purchase intentions may also reject product purchase if their experiences with website's hedonic elements, aesthetics, and functional elements are inadequate. Thus, online shopping companies i.e. PakStyle, Daraz, Lootlo, Shop Daily, Kaymu etc. should create adequate customer experience while the customer is roaming on their website to increase their purchase intentions.

\section{Limitations}

The researcher has put his best efforts to contribute to the prediction of online purchase intention, however, there are still some of the limitations in this study. This research comprises only online active internet users who shop in online environments from different locations. Thus, the sample size is limited to online users only. Those customers who have abandoned online shopping after their online experience may have different perceptions regarding product choice, satisfaction, and experience. Therefore, it is suggested to interpret research results in the light of active online users and for generalization of concept additional sample size is required.

\section{Future Directions}

In terms of future research directions, the potential researchers and scholars can investigate intervening variables as word of truth intentions, recommendation intentions, and repurchase intentions etc. as mediating variables. Moreover, researchers can also investigate customer experience and online purchase intentions in other industries i.e. Hospitality and Tourism Industry, Health and medical Industry and e- banking industry.

Sukkur IBA Journal of Management and Business | Volume 4 No. 1 January - June 2017 @ Sukkur IBA University 


\section{References}

Amoah, F., Amoah, F., Radder, L., Radder, L., van Eyk, M., \& van Eyk, M. (2016). Perceived experience value, satisfaction and behavioural intentions: A guesthouse experience. African Journal of Economic and Management Studies, 7(3), 419-433.

Arnold, M. J., \& Reynolds, K. E. (2003). Hedonic shopping motivations. Journal of retailing, 79(2), 77-95.

Babin, B. J., \& Attaway, J. S. (2000). Atmospheric affect as a tool for creating value and gaining share of customer. Journal of Business research, 49(2), 91-99.

Babin, B. J., Darden, W. R., \& Griffin, M. (1994). Work and/or fun: measuring hedonic and utilitarian shopping value. Journal of consumer research, 20(4), 644-656.

Babin, B. J., \& Zikmund, W. G. (2015). Exploring marketing research: Cengage Learning.

Bellman, S., Lohse, G. L., \& Johnson, E. J. (1999). Predictors of online buying behavior. Communications of the ACM, 42(12), 32-38.

Berry, L. L., Carbone, L. P., \& Haeckel, S. H. (2002). Managing the total customer experience. MIT Sloan management review, 43(3), 85.

Bilgihan, A. (2016). Gen Y customer loyalty in online shopping: An integrated model of trust, user experience and branding. Computers in Human Behavior, 61, 103113.

Bilgihan, A., Kandampully, J., \& Zhang, T. (2016). Towards a unified customer experience in online shopping environments: Antecedents and outcomes. International Journal of Quality and Service Sciences, 8(1), 102-119.

Biswas, D. (2009). The effects of option framing on consumer choices: Making decisions in rational versus experiential processing modes. Journal of Consumer Behaviour, 8(5), 284-299.

Burke, K. (1999). Creating a compelling online experience. Cat Age, 16, 109.

Chen, S.-C., \& Lin, C.-P. (2015). The impact of customer experience and perceived value on sustainable social relationship in blogs: An empirical study. Technological Forecasting and Social Change, 96, 40-50.

Cho, Y. K. (2015). Creating customer repurchase intention in Internet retailing: The effects of multiple service events and product type. Journal of Retailing and Consumer Services, 22, 213-222.

Constantinides, E. (2004). Influencing the online consumer's behavior: the Web experience. Internet research, 14(2), 111-126.

Constantinides, E., Lorenzo-Romero, C., \& Gómez, M. A. (2010). Effects of web experience on consumer choice: a multicultural approach. Internet research, 20(2), 188-209.

Cowles, D. L., Kiecker, P., \& Little, M. W. (2002). Using key informant insights as a foundation for e-retailing theory development. Journal of Business research, 55(8), 629-636.

Darden, W. R., \& Reynolds, F. D. (1971). Shopping orientations and product usage rates. Journal of Marketing Research, 8(4), 505-508.

Sukkur IBA Journal of Management and Business | Volume 4 No. 1 January - June 2017 @ Sukkur IBA University 
Dodds, W. B., Monroe, K. B., \& Grewal, D. (1991). Effects of price, brand, and store information on buyers' product evaluations. Journal of Marketing Research, 307-319.

Fang, Y., Qureshi, I., Sun, H., McCole, P., Ramsey, E., \& Lim, K. H. (2014). Trust, Satisfaction, and Online Repurchase Intention: The Moderating Role of Perceived Effectiveness of E-Commerce Institutional Mechanisms. Mis Quarterly, 38(2).

Fishbein, M., \& Ajzen, I. (1977). Belief, attitude, intention, and behavior: An introduction to theory and research.

Fogg, B., Soohoo, C., Danielson, D., Marable, L., Stanford, J., \& Tauber, E. (2002). How do people evaluate a Web sites's credibility. A report of research by Persuasive Technology Lab Standford University.

Garg, R., Rahman, Z., \& Qureshi, M. (2014). Measuring customer experience in banks: scale development and validation. Journal of Modelling in Management, 9(1), 87-117.

Garg, R., Rahman, Z., Qureshi, M., \& Kumar, I. (2012). Identifying and ranking critical success factors of customer experience in banks: An analytic hierarchy process (AHP) approach. Journal of Modelling in Management, 7(2), 201-220.

Gentile, C., Spiller, N., \& Noci, G. (2007). How to sustain the customer experience:: An overview of experience components that co-create value with the customer. European Management Journal, 25(5), 395-410.

Gurley, J. W. (2000). The one Internet metric that really matters. Fortune, 141(5), 392.

Hair, J., Black, W., Babin, B., \& Anderson, R. (2010). Multivariate Data Analysis Seventh Edition Prentice Hall.

Hao Suan Samuel, L., Balaji, M., \& Kok Wei, K. (2015). An investigation of online shopping experience on trust and behavioral intentions. Journal of Internet Commerce, 14(2), 233-254.

Harwood, T., \& Garry, T. (2015). An investigation into gamification as a customer engagement experience environment. Journal of Services Marketing, 29(6/7), 533-546.

Hassenzahl, M., Platz, A., Burmester, M., \& Lehner, K. (2000). Hedonic and ergonomic quality aspects determine a software's appeal. Paper presented at the Proceedings of the SIGCHI conference on Human Factors in Computing Systems.

Hassenzahl, M., \& Tractinsky, N. (2006). User experience-a research agenda. Behaviour \& information technology, 25(2), 91-97.

Hoffman, D. L., \& Novak, T. P. (1996). Marketing in hypermedia computer-mediated environments: Conceptual foundations. The Journal of Marketing, 50-68.

Holbrook, M. B., \& Hirschman, E. C. (1982). The experiential aspects of consumption: Consumer fantasies, feelings, and fun. Journal of consumer research, 9(2), 132-140.

Sukkur IBA Journal of Management and Business | Volume 4 No. 1 January - June 2017 @ Sukkur IBA University 
Homburg, C., Jozić, D., \& Kuehnl, C. (2015). Customer experience management: toward implementing an evolving marketing concept. Journal of the Academy of Marketing Science, 3(45), 377-401.

Igbaria, M., Guimaraes, T., \& Davis, G. B. (1995). Testing the determinants of microcomputer usage via a structural equation model. Journal of management information systems, 11(4), 87-114.

Ismail, A. R. (2011). Experience marketing: An empirical investigation. Journal of Relationship Marketing, 10(3), 167-201.

Kim, Y.-K. (2002). Consumer value: an application to mall and Internet shopping. International Journal of Retail \& Distribution Management, 30(12), 595-602.

Klaus, P., Gorgoglione, M., Buonamassa, D., Panniello, U., \& Nguyen, B. (2013). Are you providing the "right" customer experience? The case of Banca Popolare di Bari. International Journal of Bank Marketing, 31(7), 506-528.

Madu, C. N., \& Madu, A. A. (2002). Dimensions of e-quality. International Journal of Quality \& reliability management, 19(3), 246-258.

Maklan, S., \& Klaus, P. (2011). Customer experience: are we measuring the right things? International Journal of Market Research, 53(6), 771-792.

Martin, J., Mortimer, G., \& Andrews, L. (2015). Re-examining online customer experience to include purchase frequency and perceived risk. Journal of Retailing and Consumer Services, 25, 81-95.

Mathwick, C., Malhotra, N., \& Rigdon, E. (2001). Experiential value: conceptualization, measurement and application in the catalog and Internet

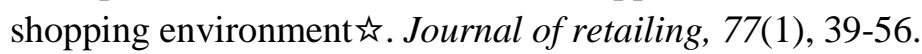

Mathwick, C., \& Rigdon, E. (2004). Play, flow, and the online search experience. Journal of consumer research, 31(2), 324-332.

Meyer, C., \& Schwager, A. (2007). Customer Experience. Harvard business review, 111.

Nunnally, J. C., \& Bernstein, I. H. (1994). Psychological theory. New York, NY: MacGraw-Hill.

O'Brien, H. L., \& Toms, E. G. (2010). The development and evaluation of a survey to measure user engagement. Journal of the Association for Information Science and Technology, 61(1), 50-69.

Pine, B. J., \& Gilmore, J. H. (1999). The experience economy: work is theatre \& every business a stage: Harvard Business Press.

Rukhsana Gul Gilal, S. X., Faheem Gul Gilal, Rehman Gul Gilal, Naeem Gul Gilal. (2016). Principles and Principals: Does Self-Concept Compete or Complement Brand Experience When Shaping Consumer Brand Relationship, Brand Preference and Customer Satisfaction? European Journal of Business and Management, 8(24), 141-157.

Schiffman, L. G., \& Kanuk, L. L. (2000). Consumer Behavior, Prentice Hall, Inc. New Jersey.

Sukkur IBA Journal of Management and Business | Volume 4 No. 1 January - June 2017 @ Sukkur IBA University 
Sekaran, U., \& Bougie, R. (2016). Research methods for business: A skill building approach: John Wiley \& Sons.

Shao, C. Y., Baker, J. A., \& Wagner, J. (2004). The effects of appropriateness of service contact personnel dress on customer expectations of service quality and purchase intention: The moderating influences of involvement and gender. Journal of Business research, 57(10), 1164-1176.

Shaw, C., \& Ivens, J. (2002). Building great customer experiences: Palgrave Macmillan.

Sheu, J.-J., Su, Y.-H., \& Chu, K.-T. (2009). Segmenting online game customers-The perspective of experiential marketing. Expert systems with applications, 36(4), 8487-8495.

Stein, A., \& Ramaseshan, B. (2016). Towards the identification of customer experience touch point elements. Journal of Retailing and Consumer Services, 30, 8-19.

Sun, L. S. (2002). The experiential dimensions of internet shopping: an ethnographic analysis of online store websites. Asian Journal of Communication, 12(2), 7999.

Sundbo, J., \& Hagedorn-Rasmussen, P. (2008). The backstaging of experience production. Creating experiences in the experience economy, 83-110.

Takatalo, J., Nyman, G., \& Laaksonen, L. (2008). Components of human experience in virtual environments. Computers in Human Behavior, 24(1), 1-15.

Woodruff, R. B. (1997). Customer value: the next source for competitive advantage. Journal of the Academy of Marketing Science, 25(2), 139-153.

Yang, Z.-Y., \& He, L.-Y. (2011). Goal, customer experience and purchase intention in a retail context in China: An empirical study. African Journal of Business Management, 5(16), 6738.

Yoo, B., \& Donthu, N. (2001). Developing a scale to measure the perceived quality of an Internet shopping site (SITEQUAL). Quarterly journal of electronic commerce, 2(1), 31-45.

Yoon, S.-J. (2013). Antecedents and consequences of in-store experiences based on an experiential typology. European Journal of Marketing, 47(5/6), 693-714.

Zeithaml, V. A. (1988). Consumer perceptions of price, quality, and value: a meansend model and synthesis of evidence. The Journal of Marketing, 2-22.

Zhou, L., Dai, L., \& Zhang, D. (2007). Online shopping acceptance model-A critical survey of consumer factors in online shopping. Journal of Electronic commerce research, $8(1), 41$.

Sukkur IBA Journal of Management and Business | Volume 4 No. 1 January - June 2017 @ Sukkur IBA University 